\title{
Pelatihan Kemampuan berfikir sebagai keterampilan melalui konsep Knowledge Convergence pada komunitas pengembang aplikasi di DiLo Depok
}

\author{
A.Z. Abdullah' ${ }^{1}$, Supratman ${ }^{2}$, Fatkhuri ${ }^{3}$ \\ Fakultas Ilmu Sosial dan Ilmu Politik, \\ Universitas Pembangunan Nasional Veteran Jakarta \\ Corresponding Email: amatzach@gmail.com
}

\begin{abstract}
ABSTRAK
Pengembangan apps memerlukan sebuah pendekatan yang partisipatif melalui upaya kolaboratif untuk mencapai tujuannya. Upaya ini adalah menggabungkan beberapa aspek seperti Bisnis, seni dan teknis yang mana sebuah fenomena yang dikenal dengan knowledge convergence. Melalui pengabdian masyarakat ini diharapkan para pegembang apps mampu mengaplikasikan beberapa kaedah dalam keterampilan berfikir yakni kritis dan kreatif untuk mampu meliputi masalah yang rumit yang memerlukan evauasi pada sudut pandang tertentu dalam mengkaji dan menyelesaikan masalah. Pengabdian masyarakat ini dilakukan di DiLO Depok untuk memenuhi kebutuhan tentang knowledege management pada komunitas pengembang aplikasi (apps). Konsep yang digunakan dalam pelatihan ini adalah Knowledge management dan kolaborasi melalui berfikir kreatif dan kritis pada proses bergagasan (ideation) hingga muncul inovasi.
\end{abstract}

Kata kunci; Berfikir kreatif, Kolaborasi, Knowledge management, Knowledge Convergence, Start-up

\section{ABSTRACT}

Apps development requires a participatory approach through collaborative efforts to achieve its goals. This effort is to combine several aspects such as business, art and technics which is a phenomenon known as knowledge convergence. Through this community service, the outcome expectation would be that apps developers are able to apply several principles of thinking skills, namely critical and creative skills which able to cover complex problems that require evaluation from a certain point of view so it would be be used as to study and solve problems. This community service was carried out at DiLO Depok to meet the needs of knowledege management in the application development community (apps). The concept used in this training knowledege managemnt and collaboration therough creative and critical thinking in the process of Ideation to emerge innovation.

Kata kunci; Creative Thinking, Collaboration, Knowledge management, Knowledge Convergence, Start-up 


\section{PENDAHULUAN}

Pengembangan aplikasi atau perangkat lunak untuk gawai mulai ramai dibicarakan sebagai lahirnya kembali bisnis digital. Para pemula ini dimulai di kalangan anak - anak muda yang biasanya berkumpul di sebuah komunitas. Digital Lounge (DiLo) Depok, adalah tempat dimana berkumpulnya komunitas pengembang perangkat lunak untuk pesawat gawai (smartphone) yang debih dikenal dengan nama apps. Perkumpulan komunitas ini juga bisa melahirkan para pengembang potensial, akan tetapi banyak dari mereka yang masih muda dan remaja sehingga memerlukan pembekalan dalam proyeknya khususnya dalam masalah pengelolaan ide. Dalam pengabdian masyarakat ini akan dilakukan sebuah pelatihan mengenai "Creative dan Critical thinking" dalam mengelola gagasan dan ide pada anggota komunitas start-up di DiLo Depok. Landasan pengabdian masyarakat ini adalah untuk menjadi bagian dari pengembangan industri ekonomi kreatif berbasis wirausaha dan juga dalam rangka memahami etika dalam berdaya saing secra global.

Dalam upaya persiapan untuk menyambut konsep pendidikan yang bersinergi dengan industri 4.0 maka diperlukan sebuah pendekatan untuk mampu melakukan tranformasi pada pandangan organisasi serta paradigma dalam menjawab tantangan zaman. Industri 4.0 dengan berbagai kompleksitas dan juga kreativitas-nya, memerlukan sebuah cara pandang yang beragam mulai dari konvergen hingga divergen, terutama untuk mengelola gagasan sehingga bisa menciptakan inovasi. Ketika kita sudah mulai menjalankan kaedah berinformasi di era komunikasi ini maka kita dipenuhi dengan berbagai informasi yang mana sebuah organisasi tidak hanya mengandalkan manajemen manusia namun juga manajemen gagasan, yang juga dikenal dengan nama knowledge management. Kaitan industri, organisasi dan pengelolaan gagasan ini merupakan sebuah implikasi dari kemajuan teknologi digital yang sudah menemani kita sejak 2007, ketika itu mulai gandrungnya menggunakan sosial media dalam kehidupan sehari - hari. Knowledge Management adalah pendekatan secara akuntabel untuk mencapai tujuan organisasi. Pendekatan ini melibatkan beberapa elemen seperti praktik sumber daya manusia, teknologi, budaya, dan struktur organisasi (Du Plessis, 2007). Knowledge managemnet adalah upaya untuk menggunakan pengetahuan dalam pengambilan keputusan secara konsisten (Lee dan Choi, 2003). Selain mengelola gagasan untuk 
pengambilan keputusan, ada juga pemahaman dan pengalaman para pelaku yang juga termasuk sebagai gagasan karena menjadi bagian dalam berfikir. Knowledge management juga adalah sebuah cara mengelola gagasan dengan menggabungkan beberapa pemahaman yang multidisiplin dan juga interdisiplin.

Memasuki tahun 2013, tren sosial di kalangan muda sudah mulai dipenuhi dengan gagasan berbisnis apalagi pemerintah sudah mulai mendorong anak muda untuk turut dalam perekonomian dalam bentuk bisnis. Sangatlah relevan ketika peran anak muda membentuk pasar di masa depan dengan mengoptimalkan media digital. Berbisnis dengan media digital banyak bentuknya, namun salah satu yang paling besar dan terbuka bagi siapapun adalah pengembangan aplikasi (apps). Pengembangan apps ini pun lebih mengkhususkan ke aplikasi gawai (smartphone) pada penyedia seperti Google Play, walaupun masih banyak domain atau platform lainnya seperti Apple Itunes, Xiomi MiStore dan sekarang Huawei AppGallery. Mereka yang baru berumur 19 tahun pun sudah berani untuk bersaing mengembangkan apps untuk bisa dijadikan komoditas.

Tahun 2020 adalah puncak dari realisasi pengembangan dari industri digital gelombang kedua yang banyak dikenal dengan technopreneur. Adanya dukungan untuk memperbanyak usaha digital terus didukung oleh pemerintah dengan mencoba menerapkan hilirisasi dalam industri digital yakni adalah "gagasan inovatif". Pemerintah Indonesia mengakui dalam upaya untuk melakukan industrilisasi baku (hilir) itu mengalami kendala yang besar karena tidak dipahami oleh dunia usaha (dikutip dari artikel "Pemerintah dukung Pengembangan start-up di Indoneisa" Media Indonesia, Oktober 2019)

Istilah "mendirikan perusahaan tanpa uang" menjadi ruh pengembangan start-up yang pada intinya bersumber pada kekuatan dan menciptakan ide untuk mendapatkan kesuksesan melainkan modal atau materi. Akan tetapi seiring berjalan para pelaku startup mulai memahami bahwa ada aspek penting dalam penciptaan ide yakni "cara berfikir". Melakukan cara berfikir ini adalah menggunakan kreativitas, dan menurut Shinta Bubu; pemilik bubu.com bahwa pengembang tidak hanya just be out of the box, we need to be out of the box and beyond the wall (Arjanti, 2012). Bahwa kotak itu hanyalah batasan kecil, kita perlu menembus "tembok" dan langkah pertamanya adalah 
memahami kotak, dan mencari tembok untuk ditembus. Bicara tentang analogi, maka hal inilah yang perlu banyak dibahas dalam berfikir kreatif.

Usaha bisnis dalam pengembangan apps sebagai salah satu start-up tentu sangat dimungkinkan untuk dikerjakan sendiri, namun dengan beberapa contoh sukses yang dibahas tentu lebih baik mengandalkan kerjasama dan memerlukan pengorganisasian kerja yang lebih luas karena mencakup daya produksi yang lebih besar. Hal inilah yang kemudian memunculkan istilah "kolaborasi" atau collaboration di kalangan pengembang apps untuk bisa menggabungkan berbagai ide dan pada saat yang sama bisa menempatkan masing - masing keahlian untuk tujuan yang sama. Pengembangan teknologi digital tentu mengandung banyak ilmu yang mendukunganya, tidak hanya sistem informasi namun juga unsur sosial, budaya, ekonomi dan juga diatur penggunaanya dalam hukum dan etika yang berlaku.

Keterkaitan antara teknologi digital, aspek sosial dan prihal organisasi tidak luput dari konvergensi, yang upayanya mencoba menggabungkan atau menyatukan berbagai aspek untuk pencapaian tujuan. Konvergensi juga dikenal sebagai upaya pemusatan yang digambarkan dengan diagram Venn yang selaras dengan kaedah multidisiplin dan interdisiplin dalam mengaplikasikan atau menerapkan ilmu.

Pendekatan pendidikan dalam menunjang peralihan masa bagi generasi ini tentu harus mencakup beberapa hal dan masih menggunakan konsep penggabungan, penyatuan dan pemusatan yang terkandung dalam konvergensi. Konsep pelatihan ini mengandalkan pendekatan yang tentu sangat erat kaitannya dengan konvergensi dengan memperhatikan kebutuhan pengaplikasiannya yang dibentuk dalam sebuah permasalahan;

- Bagaimana menerapkan konsep organisasi pada para peserta pelatihan (pengembang apps) melalui kolaborasi dengan menyesuaikan diri sesuai dengan tantangan zaman?

Dengan tujuan pelatihan yakni;

- Para peserta dapat memahami dan menerapkan kolaborasi sebagai knowledge management sebagai pengorganisasian dalam pengembangan apps. 


\section{Analisis Situasi}

Sejak munculnya berbagai program aplikasi pada gawai, tumbuh sebuah keinginan oleh masyarakat untuk bisa ikut dalam pengembagan program ini karena menjanjikan keuntungan. Antusias ini muncul dari euforia tentang berita - berita keberhasilan perusahaan kecil dayng diakuisisi oleh perusahaan raksasa seperti kaskus dan koprol, dan juga kesuksesan perusahaan digital yang memilik asset besar (unicorn) seperti Bukalapa, tokopedia, Gojek, Travelola dll.

Meningkatkanya penggunaan gawai juga diiringi dengan besarnya minat masyarakat untuk menggunakan aplikasi di dalamnya untuk kebutuhan kehidupan kita sehari hari. Aplikasi yang lebih dikenal dengan apps adalah program yang sederhana namun sangat bermanfaat dan bisa dijual untuk digunakan oleh masyarakat luas. Sebuah aplikasi juga bisa menjadi unsur pendukung untuk kegiatan yang lebih luas atau terkait partisipasi masyrakat untuk sebuah organisasi atau pemerintah negara. Keuntungan dari apps adalah dari penjulan langsung kepada pengguna, penyisipan iklan atau transaksi yang terjadi dalam apps (micro transaction).

Pengembangan apps menyangkut tiga hal, yaitu bisnis, desain dan teknis. Ketiga aspek ini mendukung berbagai unsur dalam pengembangan sehingga terbentuknya apps secara utuh. Bisnis, desain dan teknis sebenarnya adalah sebuah konvergensi dalam kolaborasi (Jeong, 2007). Bisnis adalah aspek yang melihat nilai jual dan juga pengelolaan untuk menciptaan produk serta bagaimana bisa melakukan pemasaran. Sedangkan desain menyangkut seni tampak yang mengatur tampilan UX dan UI pada apps, dan teknis (science) lebih mengurusi masalah kognisi dan kebutuhan lainnya seperti prilaku pembuat konten dan hal hal yang mencakup penelitian dalam pengembangan.

Pengembangan sebuah apps dimuali dengan ide, lalu dikelola secara teknis dan selama pengembangan harus mampu memenuhi harapan para pengelola. Semakin besar fungsi apps semakin besar orang orang yang terlibat, dengan pembiayaan dan kerumitan teknis yang harus dikelola. Pengembangan aplikasi juga termasuk dalam ekonomi kreatif, di dalamnya juga termasuk unsur dalam ekonomi kreatif seperti desain, coding serta bidang penelitian dan pengembagan (research and development).

Tentu selain biaya, tenaga dan pikiran menjadi sebuah pertimbangan dalam pengembangan aplikasi karena dianggap sebagai modal utama. Dalam perkembangannya, 
para pengembang apps membentuk sebuah komunitas tersendiri, didalamnya membahas berbagai macam upaya serta insight dalam dunia pengembangan apps. Komunitas ini biasanya berkumpul dan saling berbagi informasi dan memungkinkan adanya kerjasama atau bertukar informasi tentang kesempatan. Salah satu hal yang biasa luput dari pengaplikasian pembahasan dalam komunitas adalah Thinking as Skill, yakni berfikir pun membutuhkan keterampilan (dan juga adalah keterampulan) tidak hanya kemudian menjalankan saja. Crticical thinking as skill tentu menjadi bahasan yang hangat karena ada banyak dorongan dan permintaan untuk mengajarkan skill - skill (termasuk berfikir kreatif dan kritis) dalam menyambut era industri 4.0, selain itu juga menjadi butir penting dalam abad 21; yakni perlunya softskill dalam kurikulum. Kreatif ini juga penting sehingga bisa membentuk karakter yang kuat dalam mengambil keputusan (Maulidah, 2019). Menjadi kreatif dan kritis juga berkenaan dengan memunculkan dorongan pembelajaran dalam proses organisasi modern, karena dalam pengembangan apps membutuhkan banyak sekali insight yang biasanya harus dipelajari lebih lanjut untuk pembangunan yang baik.

Pengembagangan apps menjadi gerbang pembuka untuk bisnis dan juga pengetahuan lainnya bagi anggota komunitas. Bisa dikatakan bahwa komunitas adalah sebuah pusat pengembangan ilmu dan juga pengembangan sumber daya manusia yang berlandaskan kemasyarakatan (komunal). Hal ini juga dimungkinkan di balai pengembangan masyarakat atau yang dikenal dengan community center atau telecenters yang menjadi bagian dalam konsep pembangunan dan pemberdayaan.

Knowledge management itu sangat sarat dengan kemajuan teknologi, sehingga untuk bisa mengelola gagasan diperlukan perlakukan khusus terutama kepada pengembanganya. Pengelolaan gagasan ini juga memerlukan berbagai macam inovasi dan penerapan konsep yang mutakhir mengenai memahami cara bekerja yang dalam proses pembangunannya selaras dengan ekologi lingkungan maupun kemanusiaan.

Para pengembangan aplikasi tentu adalah inovator yang sangat memerlukan kreativitas, yang didalamnya terkandung complex thinking and solution oriented namun juga harus bisa melakukan kolaborasi karena perlunya menerapkan pendekatan multidisiplin dan interdisiplin. Dengan berbagai unsur dalam dan juga pentingnya mengaplikasikan seluruh kaedah pengembangan maka perlu ada perubahan pada sikap 
yang lama dengan menyesuaikan dengan zaman. Walaupun tuntutan ini sangatlah besar tim pengabdi masyarakat memahami bahwa yang perlu ditumbuhkan adalah kemauan untuk belajar, yakni terbukanya dengan informasi baru untuk bisa menyokong tujuan tujuan ini. Kebanyakan pengembang adalah orang - orang dengan harapan besar namun tidak mampu memahami unsur maupun kaedah kreatif karena melihatnya dari segi mikro, yakni usaha bisnis saja. Ketika seorang mempelajari hal baru belum tentu dia paham bahwa keterbaruan membawa konsweksensi untuk terbuka dan merubah sikap, membentuk sebuah jaringan dan hubungan - hubungan baru (jaringan).

Mereka yang dimaksudkan dalam pengabdian mayarakat ini adalah para pengembang yang masih baru, masih muda dan tergabung dalam community center, telecenters, komunitas atau sebuah perkumpulan. Komunikasi dan juga gaya penyampaian pun harus disesuakan sesuai dengan keadaan mereka. Kami sebelumnya merencanakan kegiatan pengabdian ini dengan ketua pelaksana kegiatan (programmer) di Dilo (digital lounge). Dilo juga dikenal sebagai co-working space yang merupakan implementasi dari program Corporate Social Responsibility oleh Peruhsahaan P.T. Telkom. Terdapat 17 Dilo di seluruh Indonesia, dan kita akan melaksakan pengabdian masyarakat ini di Dilo Depok. Abidmas ini dilakukan dengan pertemuan sebanyak 3 kali dengan output yakni menerapkan konsep - konsep kreatif pada proyek, pekerjaan mereka atau pengembangan yang mereka lakukan.

\section{Permasalah Start-Up}

Pada pelaksanaan abdimas ini juga dilakukan FGD mengenai permasalahan di dunia start-up atau apa yang menjadi kendala bagi para pemula. Masalah - masalah ini dirangkum sebagai berikut

1. Perlunya softskill seperti presentasi, bicara di depan umum, menulis laporan berkala dan "cara menjual".

2. Kebanyakan ide tentang "perusahaan tanpa uang" dalam technoprenuer sebenarnya mendorong para pelaku start-up untuk terus belajar namun kurangnya bacaan dalam bahasa Indonesia. Adapun sekarang bahan atau materi tentang pembalajaran ini masih tersebar dalam forum - forum, melalui mulut ke mulut dan terkesan tidak "serius" dan sangat panjang dan melelahkan, seharusnya ada shortcut untuk memahami materi materi ini.

3. Tidak memahami konsep bisnis secara umum, bagaimana kita bisa mengelola uang dan mencari orang atau pihak yang mau memberika uang untuk usaha mereka. 
4. Munculnya berbagai teori dan konsep tentang bagaimana melakukan bisnis tanpa kemudian melihat langsung hasilnya (empiris). Sama halnya juga melihat pasar atau mencari kesempatan. Sehingga pada kebanyakan waktu para pengembang merasa "hilang arah" dan biasanya exhausted dan kehabisan semangat sehingga kembali menengok opsi untuk menjadi karyawan saja.

5. Mampu memulai pembicaraan itu penting dalam prihal bergaul, dan juga mencari pergaulan itu juga penting sebagai inspirasi menemukan ide ide baru dan juga menyelaraskan diri dengan waktu yang tersedian untuk mengerjakan berbagai proyek dan juga belajar.

6. Bagaimana bisa menghindari overthinking? yaitu berfikir terlalu panjang dan sudah kehilangan semangat di awal awal belajar karena melihat beban kerja yang sangat berat.

7. Kebanyakan dari pengembang masih muda dan susah fokus karena selalu mudah teralihkan perhatiannya.

8. Di era pandemi seperti ini mudah sekali hilang semangat dan juga sulit menjadwalkan pekerjaan karena webinar semakin menambah dan pada keadaan yang sama terlalu banyak yang harus dilakukan jadi sulit menentukan mada yang lebih penting.

9. Sebagian besar dari ide itu tidak bisa diukur dan tidak ada parameternya sehingga banyak berimajinasi namun ketika diaplikasikan itu ternyata sulit dan butuh biaya serta banyak sekali yang harus dipahami.

10. Masih muda itu masih harus banyak mengendalikan emosi dan juga mengatur keadaan psikologis agar tetap sehat karena banyak sekali kekecewaan dari kegagalan yang dialami.

Dari FGD, tim pengabdi masyarakat melihat bahwa hal - hal yang menjadi penting dalam pelatihan ini yakni konsep yang praktis untuk pengorganisasian diri, berkomunikasi interpersonal dan cara berfikir dengan sehat.

\section{METODE}

Abdimas ini akan dilakukan dengan pertemuan sebanyak 3 kali melalui Google meet (aplikasi pertemuan, video conference berbasis internet). Hal ini dilakukan pada bulan Juli dan Juni ditengah pandemi covid19 yang terjadi di Seluruh dunia. Selain pertemuan, metode ini juga menggunakan beberapa perangkat seperti quizis (untuk membuat quiz) dan juga google classroom (untuk penyerahan tugas). Pada pertemuan terakhir peserta diminta untuk melakukan presentasi dengan mencoba menerapakan aspek - aspek kritis dan juga kreatif yang bisa mengarahkan mereka pada kolaboradi dan juga menerapkan Knowledge Convergence.

Sebelum pertemuan pertama, para peserta mendengarkan kuliah umum tentang kreatif dan kritis yang bersumber pada gagasan mengenai konvergensi yakni meliputi 
1. Industri digital adalah bagian dari ekonomi kreatif yang bertumpu pada gabungan keilmiahan (science) melalui penelitian, seni (art) melalui visualisasi, niaga (business) melalui pengorganisasian. (Kim, 2015)

2. Bahwa konsep konvergensi yang sama adalah pengembangan dari konvergensi teknologi yakni organizational, technical dan cultural aspect (Pacey, 1983)

3. Knowledge convergence adalah konsep menggabungkan beberapa pengetahuan melalui komunikasi dengan orang - orang yang pernah mengalami atau melewati suatu proses tertentu melalui dialog dialog yang kolabroatif (Jeong dan Chi, 2007)

Pada tahap selanjutnya para peserta diberikan sebuah materi tentang berfikir secara kritis atau paham kritisisme yang menjelaskan antara lain;

1. Konsep dialektis dari tradisi kritis adalah sebenarnya mencari sintesa dalam dialog tanpa konfrontatif fisik tapi menantang ide - ide itu dengan mencari cara untuk mewujudkannya, walaupun secara imajinatif.

2. Melihat masalah, atau apa yang disebut dengan kontradiksi dalam ide atau dialog.

3. Pemahaman sejarah, atau kronologi dari tradisi kritis adalah dengan mencatat semua perkembangan. Memahami proses perkembangan dengan membaca atau melakukan dialog secara rasional.

4. Membuka diri dengan self-critic dengan merefleksikan melalui berbagai dialog dengan menerapkan banyak konsep. Terbuka dengan konsep - konsep baru sebagai parameter self-critic.

Selanjutnya para peserta diberikan materi tentang kreatif dan pengorganisasian yang menjelaskan antara lain;

1. Proses kreatif atau ideation dari Graham Wallas (The art of thought), Ramsey Naseer (Transcedning the lone creator) dan Kirby Fergusson (Everything is a Remix).

2. Memahami ide sebagai gagasan yang orisinal, yaitu yang merujuk pada pengetahuan sebelumnya dan berkenaan dengan kronologi dari tradisi kritis. Memahami silsilah ide adalah kunci mengarahkan kita ke ide selanjutnya. Ide itu tidak muncul begitu saja namun meneruskan apa yang kita tahu, dan semakin kita banyak tahu dengan demikian banyak pilihan.

3. Akuntabilitas itu adalah parameter dan bisa dilakukan dengan visualisasi ide dengan menggunakan visual thinking yang diperkenalkan oleh Dan Roam (blah blah blah), Sunni Brown (Doodle Revolution) dan Austin Kleon (steal like an artist)

4. Akuntabilitas yang paling sederhana adalah proses chunking (Miller, 1956), yakni memecah pekerjaan besar menjadi bagian - bagian kecil dan disebarkan dalam keseharian (Neisser, 2014). Hal ini bisa dilakukan melalui aplikasi penjadwalan seperti iCalender atau Google Calender. 
Adapun softskill yang bisa dikembangkan dari semua materi adalah kemampuan berkomunikasi untuk berkolaborasi dengan landasan landasan sebagai berikut;

1. Bahwa modal utama dalam berkomunikasi atau bergaul adalah membagikan apa yang kita kerjakan dan mengajak orang lain juga membagi apa yang mereka kerjakan (interest sharing) dan hal ini akan lebih mudah dengan materi visual seperti powerpoint sehingga memungkinkan adanya kerja sama atau kolaborasi.

2. Konsep seperti community knowledge atau collective intelligence adalah sebenarnya banyak bergaul dengan mendengarkan orang - orang, dan sebisa mungkin banyak bertanya.

3. Membiasakan diri dengan mencatat secara visual sehingga lebih fokus pada menyampaikan bukan lagi pada substansi yang melarut - larut.

4. Menunjukan apa yang kita kerjakan secara sistematis dari blog atau sosial media (memilih satu social media saja, dalam pelatihan ini menggunakan Instagram) sebagai nilai yang bisa dipasarkan (marketing value). Bisa dilakukan dengan menjadwalkan post, content calender.

5. Melakukan chunking pada kegiatan yang mereka lakukan sekarang, dan membagi satu project dalam 3 bulan (triwulan) pengerjaan sehingga secara realistis paham bahwa dalam setahun mereka hanya memuat 4 (quarterly) project, menghindari penumpukan project.

6. Melalui chunking dan pemasaran melalui Instagram, peserta bisa tahu ukuran diri, bisa paham prioritas dan juga mendekatkan diri dengan perkembangan secara berkala. Foto - foto adalah batasan imajinasi, dan juga parameter.

7. Melakukan interaksi dengan follower sebagai engagemnet dan juga bagian dari dialog yang bisa menambah wawasan dan juga kesempatan untuk mengetahui informasi yang terbaru dengan hanya menjadi fasilitator melalui IG live. Secara berkala kegiatan ini menjadi marketing value yang lebih solid dan pada akhirnya memiliki personal branding yang baik, sehingga bisa digunakan sebagai unsur kolaborasi.

Peserta di akhir pertemuan diminta untuk melakukan perencanaan sampai tahun 2021 dengan memfokuskan diri secara quarterly. Mempresentasikan masing masing perencanaan dengan powerpoint dan dilakukan tanya jawab terhadap para peserta.

\section{HASIL \& PEMBAHASAN}

Pada akhir pertemuan banyak sekali pertanyaan mengenai tingkat keberhasilan dari apa yang mereka rencanakan dan ini menjadi bahasan yang sangat menarik untuk dibahas secara berkelanjutan. Konsep keberhasilan dan ukuran ini adalah sustainability yang memang menjadi bahasan yang sangat hangat dan harus terus dilakukan secara bertahap. Para peserta mempertanyakan "kesatuan" unit materi ini sebagai sesuatu yang 
perlu ditelaah lebih dalam sebagai pemberdayaan sehingga bisa dinyatakan secara resmi sebagai ilmu. Tim mengatakan bahwa hal ini sebenarnya adalah hal yang praktis yang diadaptasi dari ilmu produksi video yang biasa dilakukan dalam komunikasi pemasaran atau periklanan.

Para peserta dengan mudah bisa menumbuhkan kepercayaan diri dan juga bisa memberanikan diri untuk melakukan kolaborasi, dengan hasil kerja yang sudah dikerjakan sebelumnya. Memperlihatkan apa yang dikerjakan itu penting sehingga ada daya tarik yang bisa dilihat dan disaksikan oleh khalayak umum yang diantaranya bisa menjadi rekanan di masa yang akan datang.

\section{SIMPULAN}

Dalam pelatihan memang banyak sekali yang harus disempurnakan khususnya masalah justifikasi keilmuwan mengenai bergagasan atau ideation yang memang sangat sulit dicarikan sumber literaturenya. Adapun rujukan yang bisa kita sampaikan dalam pelatihan ini adalah kemampun kognitif dalam memahami proses kerja. Para peserta sangat antusias untuk mengikuti perkembangan mereka dan bagaimana hasil dari perencanaan mereka. Seluruh peserta merasa bahwa kegiatan pelatihan ini bermanfaat, menambah wawasan dan berhubungan dengan kegiatan mereka sebagai pengembang apps. Peserta berharap bahwa pelatihan ini bisa dilakukan dengan sebuat parameter atau pengukuran keberhasilan terhadap kreatif dan kritis.

\section{Daftar Pustaka}

Jeong, H., \& Chi, M. T. (2007). Knowledge convergence and collaborative learning. Instructional Science, 35(4), 287-315.

Maulidah, E. (2019, April). CHARACTER BUILDING DAN KETERAMPILAN ABAD 21 DALAM PEMBELAJARAN DI ERA REVOLUSI INDUTRI 4.0. In Prosiding Seminar Nasional PGSD UST (Vol. 1).

Pacey, A. (1983). The culture of technology. MIT press.

DuPlessis,M.(2007).The role of knowledge management in innovation. JournalofKnowledgeManagement,11(4),20-29.

Kim, H. S. (2015). A study on the convergence entrepreneurship curriculum development. Journal of digital Convergence, 13(5), 79-88.

Lee,H.,\&Choi,B.(2003). Knowledge management enablers, processes, and organizational performance: An integrative view and empirical examination. Journal of Management Information Systems, 20 (1),179-228. 
Miller, G. A. (1956). The magical number seven, plus or minus two: Some limits on our capacity for processing information. Psychological review, 63(2), 81.

Neisser, U. (2014). Cognitive psychology: Classic edition. Psychology Press.

Arhanti, R. Ajeng dan Mosal, R. Lendy. 2012 startup Indosesia. Kompas 